\title{
HUBUNGAN TINGKAT STRES DENGAN PENURUNAN SISTEM IMUN PADA MAHASISWA TINGKAT IIA AKADEMI KEPERAWATAN PANTI KOSALA SURAKARTA
}

\author{
Oleh : \\ Ditya Yankusuma Setiani ${ }^{1}$,Anisa Heni Purwanti ${ }^{2}$, Nia Asmarani $^{3}$
}

\begin{abstract}
Introduction: This study was stress is the body's response is not specific to any load and demands. Based on observations in the Academy of Nursing Panti Kosala Surakarta especially in level IIA, the authors conducted research at random to ask direct. Most of them complained of stress and dizziness since the coursework overload and besides asking also carried out objectively the data retrieval with observations. From observations made, there are approximately 10 students from 43 students experiencing symptoms such as anxious, tense and not accept lessons concentration and 4 of them have often complained of pain during a lecture.

The purpose of the research: Was to find out the relationship stress levels with decreased immune system on student level IIA Academy of Nursing Panti Kosala Surakarta.

The Subject of research: Is the entire student level IIA Academy of Nursing Panti Kosala Surakarta amounted to 43 people. The technique used is the saturated samples. Saturated samples is a way of sampling by taking all members of the population to be sampled.

The result of the research: Was the number of respondents who experienced mild stress levels of 23 respondents $(53,5 \%)$ and respondents who experienced a decline in the immune system when it is being stressed that by 30 respondents $(69,8 \%)$. From the Chi Square test results with the program SPSS version 18.0 with $\alpha=5 \%(0,05)$ acquired $p$ of 0,024 . The value of less than 0,05 $\mathrm{Ha}$ accepted meaning and $\mathrm{Ho}$ is rejected.

Conclusion of the research: Was the existence of relationship stress levels with decreased immune system on student level IIA Academy of Nursing Panti Kosala Surakarta.
\end{abstract}

Keywords: Stress Levels, Decreased Immune System

\section{PENDAHULUAN}

Stres merupakan peristiwa yang mencetuskan suatu respon pada individu yang dipengaruhi oleh persepsi individu terhadap peristiwa dan sebagai suatu hubungan antara seseorang dan lingkungan yang dianggap melampaui kemampuan dirinya dan mengancam kesejahteraan hidup. (Suliswati, et al., 2005) Imun adalah sistem pertahanan yang ada pada tubuh manusia yang berfungsi untuk menjaga manusia dari benda-benda yang asing bagi tubuh manusia. Penelitian ilmiah mengenai imunologi baru dimulai sejak Louis Pasteur pada tahun 1880, menemukan penyebab penyakit infeksi serta menetapkan teori kuman penyakit. Penurunan sistem imun dapat dipengaruhi oleh beberapa faktor diantaranya adalah faktor stres, merokok, kurangnya aktivitas/olahraga dan kurangnya jam tidur. (Hasdianah, et al., 2014) Menurut survei yang di lakukan oleh World Health Organization (WHO), 
angka kejadian stres fisik yang berakibat pada penurunan imun sejumlah 100 penduduk diantara 100.000 penduduk. Setiap tahun jumlah penderita stres di dunia bertambah kurang lebih 230.000 penderita. (Suliswati, et al., 2005)

Studi menunjukkan 1/3 masyarakat di 4 kota besar di Indonesia mengalami stres. Bagi mereka yang bekerja atau aktif, angkanya bisa naik dikisaran 70\%. Stres dapat menghabiskan vitamin B dari tubuh yang sangat penting untuk sistem menghadapi ketakutan. Itu juga dapat mengurangi penyerapan nutrisi dalam sistem tubuh dari makanan yang kita makan. Prevensi stres pasca trauma berdasarkan hasil studi sebesar 1,0\% sampai $12,3 \%$ populasi orang dewasa. Sementara koordinasi dengan penyakit psikiatrik lainnya menunjukkan diantaranya $51,9 \%$. (Sintawati, 2007)

Berdasarkan pengamatan di Akademi Keperawatan Panti Kosala Surakarta khususnya di tingkat II A, penulis melakukan penelitian secara acak dengan tanya jawab. Sebagian besar dari mereka mengeluhkan stres dan pusing karena tugas-tugas yang membebaninya dan selain dengan tanya jawab juga dilakukan pengambilan data secara objektif yaitu dengan pengamatan. Dari pengamatan yang telah dilakukan ada kurang lebih 10 mahasiswa dari 43 mahasiswa mengalami gejalagejala seperti sering terlihat cemas, tegang dan tidak konsentrasi menerima pelajaran dan 4 diantaranya sering mengeluh sakit selama kuliah.

Dari latar belakang di atas penulis berminat meneliti hubungan tingkat stres dengan penurunan sistem imun pada mahasiswa tingkat IIA Akademi Keperawatan Panti Kosala.

\section{TUJUAN PENELITIAN}

Secara umum tujuan penelitian ini adalah untuk mengetahui hubungan tingkat stres dengan penurunan sistem imun pada mahasiswa tingkat IIA Akademi Keperawatan Panti Kosala Surakarta.

\section{DESAIN PENELITIAN}

Penelitian ini merupakan jenis penelitian analitik, dengan desain penelitian korelasi dan pendekatan cross sectional. Penelitian ini bertujuan untuk menghubungkan tingkat stres sebagai variabel bebas dengan penurunan sistem imun sebagai variabel terikat.

\section{POPULASI, SAMPEL, TEKNIK SAMPLING}

Populasi merupakan seluruh subyek atau objek dengan karakteristik tertentu yang akan diteliti. (Hidayat, 2008) Populasi pada penelitian ini adalah mahasiswa Akademi Keperawatan Panti Kosala Surakarta pada tingkat IIA sejumlah 43 orang.

Sampel merupakan bagian populasi yang akan diteliti atau sebagian jumlah dari karakteristik yang dimiliki oleh populasi. (Hidayat, 2008) Pada penelitian ini peneliti mengambil seluruh populasi untuk dijadikan sampel yaitu sejumlah 43 orang.

Teknik sampling merupakan suatu proses seleksi sampel yang digunakan dalam penelitian dari populasi yang ada, sehingga jumlah sampel akan mewakili keseluruhan populasi yang ada. (Hidayat, 2008) Teknik sampling yang peneliti gunakan adalah teknik sampling jenuh, dimana cara pengambilan sampel dengan mengambil semua anggota populasi menjadi sampel. (Hidayat, 2008) Dalam penelitian ini, peneliti menggunakan 43 orang untuk dijadikan sampel peneliti. 


\section{HASIL PENELITIAN}

Penelitian ini dilakukan mulai bulan November 2014 sampai dengan Februari 2015. Responden di dalam penelitian ini yaitu mahasiswa tingkat IIA Akademi Keperawatan Panti Kosala Surakarta yang berjumlah 43 responden.

Tabel 1. Distribusi Frekuensi Tingkat Stres

\begin{tabular}{ccc}
\hline Tingkat Stres & $\mathrm{F}$ & $\%$ \\
\hline Ringan $(<150)$ & 23 & 53.5 \\
\hline Sedang $(150-299)$ & 17 & 39.5 \\
\hline Berat $(>300)$ & 3 & 7.0 \\
\hline Jumlah & 43 & $100 \%$
\end{tabular}

Berdasarkan tabel di atas, ditemukan sebagian besar responden memiliki tingkat stres ringan yaitu 23 responden (53,5\%), memiliki tingkat stres sedang yaitu 17 responden $(39,5 \%)$ dan responden dengan tingkat stres berat ada 3 responden $(7,0 \%)$.

Dari data di atas diperoleh nilai mean (rata-rata) tingkat stres pada responden sebanyak 149, sedangkan median (nilai tengah) sebanyak 147, modus (nilai yang sering muncul) adalah 104 dan standar deviasi sebanyak 77,4 . Hal ini membuktikan bahwa sebagian besar responden mengalami tingkat stres ringan.

Tabel 2. Distribusi Frekuensi Penurunan Sistem Imun

\begin{tabular}{ccc}
\hline $\begin{array}{c}\text { Penurunan Sistem } \\
\text { Imun }\end{array}$ & $\mathrm{F}$ & $\%$ \\
\hline Ada penurunan & 30 & 69.8 \\
\hline Tidak ada penurunan & 13 & 30.2 \\
\hline Jumlah & 43 & 100 \\
\hline
\end{tabular}

Berdasarkan tabel di atas, ditemukan sebagian besar responden mengalami penurunan sistem imun ketika sedang dihadapkan pada stresor yaitu sebesar 30 responden $(69,8 \%)$, sedangkan 13 responden $(30,2 \%)$ tidak mengalami penurunan sistem imun saat menghadapi stressor.

Tabel 3. Tabulasi Silang Tingkat Stres dengan Penurunan Sistem Imun

\begin{tabular}{|c|c|c|c|c|c|}
\hline \multirow{3}{*}{$\begin{array}{l}\text { Tingkat } \\
\text { Stres }\end{array}$} & \multicolumn{2}{|c|}{$\begin{array}{l}\text { Penurunan } \\
\text { Sistem Imun }\end{array}$} & \multirow{2}{*}{\multicolumn{2}{|c|}{ Total }} & \multirow{3}{*}{$\mathrm{P}$} \\
\hline & \multirow{2}{*}{$\begin{array}{c}\text { Ada } \\
f\end{array}$} & \multirow{2}{*}{$\begin{array}{c}\text { Tidak } \\
\text { Ada } \\
f\end{array}$} & & & \\
\hline & & & $f$ & $\%$ & \\
\hline Ringan & 12 & 11 & 23 & 53,5 & \\
\hline Sedang & 15 & 2 & 17 & 39,5 & .024 \\
\hline Berat & 3 & 0 & 3 & 7,0 & \\
\hline
\end{tabular}

Berdasarkan tabel di atas, dapat dilihat bahwa pada responden dengan tingkat stres ringan yang mengalami penurunan sistem imun ada 12 responden, dan 11 responden tidak mengalami penurunan sistem imun. Pada responden dengan tingkat stres sedang yang mengalami penurunan sistem imun ada 15 responden, dan yang tidak mengalami penurunan sistem imun ada 2 responden. Sedangkan responden dengan tingkat stres berat yang mengalami penurunan sistem imun ada 3 responden dan tidak ada yang mengalami penurunan sistem imun. Jadi jumlah responden yang mengalami tingkat stres ringan sebesar 23 responden (53,5\%), tingkat stres sedang 17 responden $(39,5 \%)$ dan tingkat stres berat sebesar 3 responden (7,0\%). Jumlah responden yang mengalami tingkat stres ringan sebesar 23 responden $(53,5 \%)$, dan yang tidak mengalami penurunan sistem imun sebanyak 13 responden.

Dari hasil uji Chi-Square dengan program SPSS versi 18.0 dengan $\alpha$ $=5 \%(0,05)$ diperoleh $\mathrm{p}$ sebesar 0,024 . Nilai tersebut kurang dari 0,05 yang berarti $\mathrm{Ha}$ diterima dan $\mathrm{Ho}$ ditolak sehingga ada hubungan antara tingkat stres dengan 
penurunan sistem imun pada mahasiswa tingkat II A Akademi Keperawatan Panti Kosala Surakarta.

Tabel 4. Statistik Uji Chi-Square

\begin{tabular}{ccccc}
\hline & Value & Df & $\begin{array}{c}\text { Asymp } \\
\text { Sig. } \\
(2- \\
\text { sided) }\end{array}$ & $\begin{array}{c}\text { Ap } \\
\text { por } \\
\text { ox. } \\
\text { Sig }\end{array}$ \\
\hline $\begin{array}{ccccc}\text { Pearson Chi- } \\
\text { Square }\end{array}$ & 7.424 & 2 & .024 & \\
\hline $\begin{array}{c}\text { Contingency } \\
\text { Coeffiecient }\end{array}$ & .384 & & & .024 \\
\hline
\end{tabular}

Dari tabel di atas dapat dilihat pada Pearson Chi Square yaitu 0,024 (probabilitas < 0,05) sehingga $\mathrm{Ha}$ diterima, yang berarti ada hubungan yang signifikan antara tingkat stres dengan penurunan sistem imun pada mahasiswa tingkat IIA Akademi Keperawatan Panti Kosala Surakarta. Akan tetapi besarnya hubungan sangat rendah yaitu 0,384 atau $38,4 \%$ dilihat dari nilai Contingency Coeffiecient.

\section{PEMBAHASAN}

1. Tingkat Stres

Pada hasil penelitian, sebagian besar responden memiliki tingkat stres ringan yaitu 23 responden $(53,5 \%)$, memiliki tingkat stres sedang yaitu 17 responden $(39,5$ $\%)$ dan responden dengan tingkat stres berat ada 3 responden $(7,0$ $\%)$. Dari hasil analisa univariat didapatkan hasil mean dalam penelitian ini 149, median atau nilai tengah dalam penelitian tingkat stres ini didapatkan 147 dan modus dalam penelitian ini adalah 104 yang menunjukkan bahwa tingkat stres yang paling banyak muncul pada responden adalah tingkat stres ringan. Penilaian status stres dilakukan dengan menggunakan skala penghitungan penyesuaian sosial yang diciptakan oleh Thomas Holmes dan Richard Rahe yang berisi daftar peristiwa hidup yang biasa dialami seseorang. Alat ukur ini didesain berdasarkan kesimpulan bahwa perubahan dalam hidup adalah faktor utama dalam timbulnya stres. Sehingga semakin banyak peristiwa hidup yang dialami seseorang, maka semakin besar pula perubahanperubahan yang dihadapi, dan semakin tinggi resiko untuk terjadinya stres. (Suliswati, et al., 2005)

Berat ringannya stres dipengaruhi oleh mekanisme koping yang dimiliki oleh individu tersebut. Koping merupakan suatu tindakan mengubah kognitif secara konstan dan usaha tingkah laku untuk mengatasi tuntutan internal maupun eksternal yang dinilai membebani atau melebihi sumber daya yang dimiliki oleh individu. Menurut Nasir dan Muhith (2011), ada beberapa pencetus stres yang perlu diwaspadai yaitu perilaku, perasaan, sensasi tubuh, penghayatan mentalitas, proses berpikir merangkai pengertian, hubungan antar manusia dan obat-obatan. Pada kuesioner tentang tingkat stres, ditemukan bahwa pencetus dari stres mahasiswa sebagian besar yaitu 18 responden pernah mengalami perubahan tingkah laku dari teman bermain dan 16 responden putus dengan pacar, dimana hal ini sesuai dengan teori pencetus stres menurut Nasir dan Muhith (2011) yaitu berdasarkan hubungan antarmanusia bahwa apabila hubungan kita bermasalah dengan orang lain akan sangat berpengaruh pada kondisi stres, dan pencetus yang lainnya adalah perubahan keuangan pada keluarga yaitu sebesar 16 responden, hal ini sesuai dengan teori pencetus stres berdasarkan penghayatan mentalitas bahwa mentalitas yang 
buruk, seperti perasaan gagal, perasaan tidak berguna, atau berpikir bahwa dirinya ditakdirkan untuk hidup miskin maka akan dapat menyebabkan masalah dan timbulnya stres dalam diri individu tersebut. Pencetus-pencetus stres tersebut jika tidak disadari bisa berakibat pada tingkat stres yang lebih lanjut. Pada responden yang memiliki tingkat stres sedang dan bahkan berat, dapat dikarenakan tidak menyadari dari awal adanya faktor-faktor pencetus tersebut dan didukung dengan mekanisme koping yang tidak efektif.

2. Penurunan Sistem Imun

Dari hasil penelitian tentang penurunan sistem imun, didapatkan bahwa sebagian besar responden mengalami penurunan sistem imun ketika sedang dihadapkan pada stressor yaitu sebesar 30 responden $(69,8 \%)$ yang ditandai dengan peningkatan tekanan darah ketika sedang stress dan penurunan berat badan secara drastis ketika sedang stres. Hal tersebut membuktikan bahwa responden sedang mengalami tanda dan gejala dari penurunan sistem imun sesuai dengan teori yang dijabarkan oleh Hasdianah, et al. (2014), bahwa tanda gejala subjektif dari penurunan sistem imun adalah jika terjadi perlukaan mengalami perpanjangan penyembuhan, mengalami peningkatan tekanan darah, penurunan berat badan secara drastis, flu dan diare yang tidak kunjung sembuh, mengalami gangguan lambung yang tidak kunjung sembuh.

Penurunan sistem imun tersebut dapat terjadi apabila sistem kekebalan tubuh tidak mampu menjaga tubuh dari serangan luar maupun dari dalam. Penyebab dari penurunan sistem imun (penurunan daya tahan tubuh) adalah jam tidur yang kurang, stres, merokok, kurangnya aktivitas fisik/olahraga. (Proverawati dan Rahmawati, 2012) Dari hasil kuesioner didapatkan bahwa 37 mahasiswa menjawab sering lembur untuk menyelesaikan tugas-tugasnya sehingga waktu untuk tidur sangatlah kurang. Sebagaimana yang dikemukakan oleh Kozier et al. (2010), bahwa remaja memerlukan 8-10 jam waktu tidur setiap malam untuk mencegah keletihan yang tidak perlu dan kerentanan terhadap infeksi. Pada kuesioner didapatkan jawaban dari sebagian besar responden ketika dihadapkan pada stresor, maka tekanan darah akan meningkat yaitu 19 responden, berat badan turun sebesar 21 responden, secara teori bahwa stres dapat mempengaruhi sistem kekebalan tubuh dengan mengganggu komunikasi antara sistem saraf endokrin dan sistem kekebalan tubuh. Seseorang yang sedang mengalami stres yang ditangkap oleh panca indranya, melalui sistem saraf pusat indra akan diteruskan ke susunan saraf pusat otak yaitu limbik. Selanjutnya stimulus psikososial tadi melalui susunan saraf autonom akan diteruskan ke kelenjar adrenalin yang letaknya di atas organ ginjal. Rangsangan tadi akan mengakibatkan produksi hormon adrenalin meningkat kemudian masuk dalam peredaran darah dan mempengaruhi jantung (berdebar-debar), tekanan darah meningkat, asam lambung meningkat, emosi tidak terkendali. (Hawari, 2006) 
3. Hubungan Tingkat Stres dengan Penurunan Sistem Imun

Berdasarkan analisa bivariat hubungan tingkat stres dengan penurunan sistem imun didapatkan hasil bahwa ada hubungan antara tingkat stres dengan penurunan sistem imun pada mahasiswa tingkat II A Akademi Keperawatan Panti Kosala Surakarta. Hal ini ditunjukkan dengan nilai Pearson Chi Square sebesar 0.024 (probabilitas < 0,05) dan besarnya hubungan ini rendah yaitu 0,384 atau $38,4 \%$ dilihat dari nilai Contingency Coeffiecient. Jumlah responden yang mengalami tingkat stres ringan sebesar 23 responden $(53,5 \%), \quad 12$ responden mengalami penurunan sistem imun dan 11 responden tidak mengalami penurunan sistem imun. Sedangkan responden dengan tingkat stres sedang sebesar 17 responden 39,5\%, 15 diantaranya mengalami penurunan sistem imun dan 2 responden tidak mengalami penurunan sistem imun. Responden dengan tingkat stres berat sebesar 3 responden (7\%) dimana ketiga responden tersebut mengalami penurunan sistem imun. Hasil uji silang tersebut membuktikan bahwa ada hubungan tingkat stres dengan penurunan sistem imun, dimana responden yang mengalami stres baik tingkat ringan, sedang maupun berat lebih besar kemungkinan mengalami penurunan sistem imun.

Hasil penelitian ini sejalan dengan penelitian terdahulu oleh Mayasari (2009) bahwa ada hubungan antara respon imun dengan stres dan juga penelitian Banun dan Sandra (2013) yang menyatakan bahwa ada hubungan stres dengan penyakit periodontal. Pada kuesioner didapatkan jawaban dari sebagian besar responden ketika dihadapkan pada stresor, maka tekanan darah akan meningkat dan berat badan turun drastis. Dari hasil jawaban responden tersebut dapat ditarik kesimpulan bahwa stres yang tidak segera diatasi akan dapat menyebabkan seseorang jatuh sakit. Menurut Hawari (2006), bahwa psikoneuroimunologi adalah ilmu yang mempelajari hubungan antara faktor psikososial, sistem saraf dan kekebalan tubuh. Seseorang yang sedang mengalami stres yang ditangkap oleh panca indranya, melalui sistem saraf pusat indra akan diteruskan ke susunan saraf pusat otak yaitu limbik. Selanjutnya stimulus psikososial tadi melalui susunan saraf autonom akan diteruskan ke kelenjar adrenalin yang letaknya di atas organ ginjal. Rangsangan tadi akan mengakibatkan produksi hormon adrenalin meningkat kemudian masuk dalam peredaran darah dan mempengaruhi jantung (berdebar-debar), tekanan darah meningkat, asam lambung meningkat, emosi tidak terkendali. Stimulus atau rangsangan psikososial tadi mulanya merupakan gangguan fungsional organ tubuh saja akan tetapi jika berkelanjutan dapat menyebabkan kelainan pada organ tubuh itu sendiri atau dengan kata lain organ tubuh itu sakit. Hal tersebut telah membuktikan bahwa memang ada hubungan tingkat stres dengan penurunan sistem imun.

\section{KESIMPULAN}

Berdasarkan pembahasan di atas maka dapat ditarik kesimpulan bahwa ada hubungan tingkat stres 
dengan penurunan sistem imun pada mahasiswa tingkat II A Akademi Keperawatan Panti Kosala Surakarta. Hal ini dibuktikan dari hasil Chi-Square dengan program SPSS versi 18.0 dengan $\alpha=5 \%$ $(0,05)$ diperoleh $p$ sebesar 0,024 . Nilai tersebut kurang dari 0,05 yang berarti Ha diterima dan Ho ditolak.

\section{SARAN}

Berdasarkan hasil penelitian dan kesimpulan di atas maka penelitian ini diharapkan agar mahasiswa bisa menggunakan koping yang efektif untuk mengatasi setiap masalah sehingga tingkat stres tidak berlanjut ke tingkat stres yang lebih berat. Selain itu tingkat stres bukan satusatunya faktor yang mempengaruhi penurunan sistem imun, akan tetapi masih ada beberapa faktor yang dapat mempengaruhi penurunan sistem imun diantaranya faktor merokok, olahraga dan kurangnya jam tidur. Oleh karena itu, diharapkan agar peneliti selanjutnya melanjutkan penelitian dengan variabel faktor-faktor lain yang mempengaruhi penurunan sistem imun tersebut.

\section{DAFTAR PUSTAKA}

George, Hendra. Mengenal Gangguan Jiwa Sejak Dini. Surakarta: CV Karya Mandiri, 2007.

Hasdianah, et al. IMUNOLOGI Diagnosis dan Teknik Biologi Molekuler. Yogyakarta: Nuha Medika, 2014.

Hawari, Dadang. Stres Cemas dan Depresi. Jakarta: Balai Penerbit FKUI, 2006.

Hidayat, Aziz Alimul. Pengantar Konsep Dasar Keperawatan. Jakarta: Salemba Medika, 2008.
Metodologi Penelitian Keperawatan dan Teknik Analisis Data. Jakarta: Salemba Medika, 2009.

. Riset Keperawatan dan Teknik Teknik Penulisan IImiah. Jakarta: Salemba Medika, 2008.

Kozier, Barbara, et. al. Buku Ajar Fundamental Keperawatan Konsep Proses dan Praktik. Alih Bahasa : Esty Wahyuningsih. et. al. Jakarta : EGC, 2010.

Nasir, Abdul dan Abdul Muhith. Dasar-Dasar Keperawatan Jiwa. Jakarta: Salemba Medika, 2011.

Proverawati, Atikah dan Eni Rahmawati. Perilaku Hidup Bersih dan Sehat. Yogyakarta: Nuha Medika, 2012.

Riwidikdo, Handoko. Statistik Kesehatan Belajar Mudah Teknik Analisis Data Dalam Penelitian Kesehatan. Yogyakarta: Mitra Cendikia Press, 2007.

Suliswati, et al. Konsep Dasar Keperawatan Kesehatan Jiwa. Jakarta: EGC, 2005.

Suyanto. Metodologi dan Aplikasi Penelitian Keperawatan. Yogyakarta: Nuha Medika, 2011.

Sintawati, Hiasinta. Taklukkan Stres Untuk Selamanya. Tangerang: Interaksara, 2007. 

Banun dan Desi Sandra. Dampak Stress Dan Psikososial Terhadap Keparahan Penyakit Periodontal Pada Pengungsi Pasca Banjir Bandang Di Desa Kemiri, Panti, Jember. 2013.

Mayasari, Pratiwi. Hubungan Respon Imun dan Stres dengan pada Masyarakat di Wilayah Puskesmas Colomadu Karanganyar. 2009.

1 Dosen AKPER Panti Kosala Surakarta

2 Mahasiswa AKPER Panti Kosala Surakarta

3 Mahasiswa AKPER Panti Kosala Surakarta 